\title{
RECENZJA KSIĄŻKI PAULI M. NIEDENTHAL, SYLVII KRAUTH-GRUBER, FRANCOIS RIC ZROZUMIEĆ EMOCJE. PERSPEKTYWY POZNAWCZE I PSYCHOSPOEECZNE, WYDAWNICTWO NAUKOWE UNIWERSYTETU PEDAGOGICZNEGO, KRAKÓW 2016
}

\author{
THE REVIEW OF THE BOOK UNDERSTANDING EMOTIONS. COGNITIVE AND \\ PSYCHOSOCIAL PERSPECTIVES BY PAULA M. NIEDENTHAL, SYLVIA KRAUTH-GRUBER, \\ FRANCOIS RIC, THE PEDAGOGICAL UNIVERSITY OF CRACOW PUBLISHING HOUSE, \\ CRACOW 2016
}

\author{
Anna Maria Jeznach \\ Collegium Mazovia Innowacyjna Szkoła Wyższa w Siedlcach
}

Jeznach A.M. (2017), Recenzja książki Pauli M. Niedenthal, Sylvii Krauth-Gruber, Francois Ric „Zrozumieć emocje. Perspektywy poznawcze i psychospołeczne". Rozprawy Społeczne, 11 (2), s. 67-68.

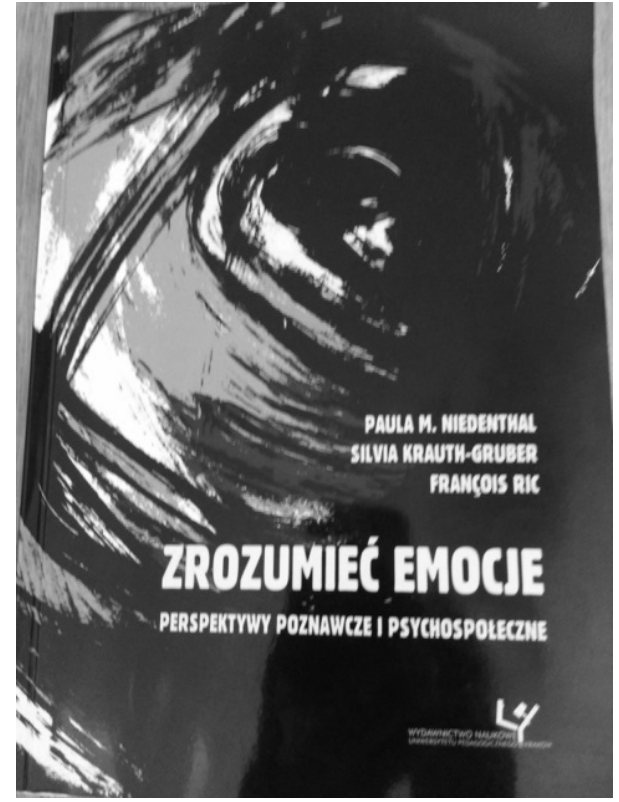

Kategoria emocji stanowi od dawna przedmiot zainteresowania psychologów (m. in. Reykowski 1968; Lewis, Haviland-Jones 2005; Łosiak 2007; P. Ekman 2012; P. Ekman, R.J. Davidson 2012), ale również socjologów (Binder, i in. 2009; Konecki, Pawłowska 2014; Rajtar, Straczuk 2012; Turner, Stets 2009).

$\mathrm{Na}$ temat natury i rozwoju reprezentacji emocji pisali: Tomasz Maruszewski, Elżbieta Ścigała (1998); Małgorzata Stepień-Nycz (2015). O konsekwencjach potocznego rozumienia emocji możemy przeczytać w pracy Anny Jasielskiej (Jasielska 2013), a o związku emocji z motywacją w książce Brin'a Parkinsona, Andrew'a M Colmana (1994, 1995). Psychologiczną teorię atrybucji (z uwzględnieniem emocji moralnych, kategorii sprawiedliwości i motywacji społecznej) znajdziemy w pracy Bernarda Weinera (Weiner 2012).

Mimo tak szerokiego spektrum perspektyw, ujęć, obszarów zainteresowań, wielu sporów wśród samych psychologów badających emocje istnieje pewna zgodność, co do tego, że emocje to: „stany intencjonalne, wartościujące (aprobata lub dezaprobata), stany mniej lub bardziej chwilowe i krótkotrwałe" (Parkinson, Colman 1995, s.16).

Za największy atut książki Pauli M. Niedenthal, Sylvii Krauth-Gruber, Francois Ric, (2016), Zrozumieć emocje. Perspektywy poznawcze i psychospołeczne, Wydawnictwo Naukowe Uniwersytetu Pedagogicznego, Kraków, należy uznać holistyczne ujecie fenomenu emocji. Autorzy zrealizowali założone cele:

- scharakteryzowali pojęcie emocji;

- przedstawili naturę emocji na każdym poziomie analizy psychologicznej;

- omówili i porównali ogólne teorie emocji;

- pokazali relacji miedzy poznaniem a emocją;

- uwzględnili dominującą roli kultury, płci w doświadczeniu emocjonalnym (s. 6).

Praca mieści się w polu badawczym ogólnej psychologii emocji (s. 5). Ukazuje ona perspekty-

Adres korespondencyjny: Anna Maria Jeznach, Collegium Mazovia Innowacyjna Szkoła Wyższa w Siedlcach, ul. Sokołowska 161, 08-110 Siedlce, e-mail: ajeznach@mazovia.edu.pl, tel.: 256333032

Copyright by: Państwowa Szkoła Wyższa im. Papieża Jana Pawła II w Białej Podlaskiej, Anna Maria Jeznach

Czasopismo Open Access, wszystkie artykuły udostępniane są na mocy licencji Creative Commons Uznanie autorstwa-użycie niekomercyjne-na tych samych warunkach 4.0 Międzynarodowe (CC BY-NC-SA 4.0, http://creativecommons.org/licenses/by-nc-sa/4.0/). 
wy poznawcze i psychospołeczne emocji, rzetelnie przedstawia międzynarodowy charakter badań nad emocjami. Autorzy ukazują znaczenie emocji w życiu człowieka, akcentując ich centralną rolę w zachowaniu człowieka. Uwagę zwraca podkreślana przez autorów problematyczność rozumienia emocji (najważniejsze wyzwanie XXI w.). Autorzy próbuja odpowiedzieć na pytania, które od dawne są źródłem niepokojów psychologów, m.in.

- Jak w ogóle można badać emocje? Jak je mierzyć?

- W jaki sposób sytuacje społeczne, procesy społeczne warunkują doświadczenie emocjonalne?

- Jak można oddziaływać na kontrolę emocji?

- Jaki jest wpływ stanów emocjonalnych (szczególnie negatywnych) na nasze zdrowie?

- Jakie znaczenie ma epoka, w której żyjemy, kultura w naszym doświadczeniu emocjonalnym? (s. 5)

W poszczególnych rozdziałach znajdują się kardynalne determinanty konstytuujące emocje: analiza emocji pod kątem różnych składników, funkcji oraz sposobów oddziaływania na interakcje społeczne (czynniki społeczne) oraz znaczenie biologii w doświadczeniu emocjonalnym (biologia).

Książka składa się z dziewięciu głównych rozdziałów, podsumowania, bibliografii i indeksu tematycznego. Można w niej odnaleźć następujące obszary tematyczne: Czym są emocje w jaki sposób są badane?; Struktura i funkcje emocji; Emocje świadomościowe; Mimika związana z emocjami; Regulowanie emocjami; Emocje w społecznym poznaniu; Emocje i procesy grupowe; Emocje a różnice płciowe, Emocje a kultura (s. 9-314).

Wysoki poziom merytoryczny i metodologiczny powoduje, że praca może być rekomendowana zarówno studentom nauk humanistycznych i społecznych, nauk o zdrowiu i kulturze fizycznej chcących uporządkować wiedzę na temat emocji, ale również pracownikom naukowym interesującym się kategorią emocji, którym trudno jest uporządkować stany i doświadczenia mieszczące się w jej ramach.

\section{Literatura:}

1. Binder P., Palska H., Pawlik W. (red.) (2009), Emocje a kultura i życie społeczne. Wydawnictwo IFiS PAN, Warszawa.

2. Ekman P. (2012), Emocje ujawnione. Odkryj, co ludzie chca przed Tobq zataić i dowiedz się czegoś więcej o sobie. Wydawnictwo Helion SA, Gliwice.

3. Ekman P. Davidson R.J. (red. nauk.) (2012), Natura emocji. Podstawowe zagadnienia. SGWP, Sopot.

4. Jasielska A. (2013), Charakterystyka i konsekwencje potocznego rozumienia emocji. Wydawnictwo Naukowe UAM, Poznań.

5. Konecki K.T., Pawłowska B. (red.), (2014), Emocje w życiu codziennym. Analiza kulturowych, społecznych i organizacyjnych uwarunkowań ujawniania i kierowania emocjami. Wydawnictwo Uniwersytetu Łódzkiego, Łódź.

6. Lewis M., Haviland-Jones J.M. (red.) (2005), Psychologia emocji, Gdańskie Wydawnictwo Psychologiczne, Gdańsk.

7. Łosiak W. (2007), Psychologia emocji. Wydawnictwa Akademickie i Profesjonalne, Warszawa.

8. Maruszewski T., Ścigała E. (1998), O naturze i rozwoju reprezentacji emocji. Przegląd Psychologiczny, 40 (1-2), s. 81-108.

9. Parkinson B., Colman A. $(1994,1995)$, Emocje i motywacja. Wydawnictwo Zysk i S-ka, Poznań.

10. Rajtar M., Straczuk J. (red.) (2012), Emocje w kulturze. Wydawnictwo Uniwersytetu Warszawskiego, Narodowe Centrum Kultury, Warszawa.

11. Reykowski J. (1968), Eksperymentalna psychologia emocji. Książka i Wiedza, Warszawa.

12. Stępień-Nycz M. (2015), Rozwój reprezentacji emocji w dzieciństwie. Wydawnictwo Stowarzyszenia Filomatów, Warszawa.

13. Turner J.H., Stets J.E. (2009), Socjologia emocji. Wydawnictwo Naukowe PWN, Warszawa.

14. Weiner B. (2012), Emocje moralne, sprawiedliwość i motywacje społeczne. Wydawnictwo Smak Słowa, Sopot. 